\title{
ISLAM AND HUMAN RIGHTS IN INDONESIA: An Account of Muslim Intellectuals' Views*
}

\author{
Ahmad Nur Fuad; Arbaiyah; Syafiq Mughni; and Achmad Jainuri \\ Faculty of Adab, State Institute for Islamic Studies "Sunan Ampel" \\ Surabaya
}

\section{Abstract}

The issue of Islam and human rights has become important issue in Indonesia at least since the last two decades. Indonesian Muslims have developed two different approaches to buman rights: in complete agreement with the declaration of universal buman rights; and in resistance to that declaration and developing understanding that Islam encompasses buman rights values. The article argues for its part that buman rights are not absolutely universal, because they are based chiefly on Western values, structures, ethics and morality. For that, it is reasonable to question their universality. The present article focuses on how Indonesian Muslim intellectuals conceive of human rights and Islamic values as they perceive the two. Specifically, it focuses on four principal issues in human rights discourse: freedom of opinion, religious freedoms, rights of women, and criminal law. The authors reveal in the conclusion that although some Indonesian Muslim intellectuals admit that universal human rights are truly universal, they still see differences in certain cases, due to differences

* This paper is based on a research which was undertaken with the financial support of the Government of Canada provided through the Canadian International Development Agency (CIDA) and the Government of Indonesia provided through Ministry of Religious Affair (MORA) in 2002-2003. Special thank is due to Professor Wael B. Hallaq (McGill University), whose supervision and useful critical insight have made this research report possible. 
Ahmad Nur Fuad, et al.

in socio-cultural background. They have tried to affect a synthesis between the universality and particularity of both Islamic and universal buman rights in order to make both fit within the Indonesian context.

Keyword: human rights, religious freedom, women rights, freedom of expression

\section{A. Introduction}

The issue of human rights has attracted the attention of a number of Indonesian Muslim intellectuals, and has developed as a significant topic of public discourse particularly in the last two decades. ${ }^{1}$ Different opinions on this issue have been stated, even though none have been presented in an elaborate and comprehensive way. Human rights issues are, however, undoubtedly attractive today to activists and intellectuals. They are discussed extensively in theoretical discourse, while their implementation in state and society is much sought-after. The efforts of activists have gained momentum as the demands for the establishment of a democratic political system and the foundation of a civil society have grown significantly. A number of activists and intellectuals have in fact devoted their energy to discussing, formulating and promoting human rights on both the theoretical and practical levels. ${ }^{2}$

It is important first to assert that Indonesia is not an Islamic state, because it does not make use of Islam as the ideology of state. However, this certainly does not mean that Indonesia is absolutely a secular state, since the role of Islam is pivotal and significant in the development of this country where the majority of the population is Muslim. It has been recognized that Islamic values play a prominent role in Indonesian society, including politics. In this regard, discourse on human rights and their implementation can hardly be separated from Islam and Muslim society.

1 Indonesian politicians did in fact deal with the same issue in debates in the Konstituante (Legislative Assembly resulted from 1955 election) between 1956 and 1959, as will be shown below.

2 Muhammad A.S. Hikam, "Islam and Human Rights: Tension and Possible Cooperation: The Case of Indonesia", The Asia Foundation Report No.24 (February, 1997), pp. 1-5; available at http://www.asiafoundation.org.publications/ rpt_other1.html. 
Despite the fact that Islam plays a paramount role in state and society, tensions among Muslim intellectuals, and between Islam and the state cannot be easily avoided. The division is apparent wherever Muslim intellectuals engage in discussing the relationship between Islam and politics, democracy, and human rights. The emergence of different and diverse viewpoints on Islam is, at this time, clearly discernible. Thus, Islam in Indonesia, just as in the wider Muslim world, is not a single, monolithic phenomenon. Even in Islam's encounter with state affairs, it manifests itself in a variety of expressions, ranging from a secular tendency to a fundamentalist standpoint.

The most salient phenomenon taking place in the context of that process has been the growing intensity of political and human rights discourse among the larger segment of Indonesian Muslim intellectuals. This fact reveals that, whatever their standpoint on Islam, Muslim scholars and activists deem it their responsibility to offer an interpretation of Islamic doctrines that is compatible with humanity in general. For although some Muslim scholars claim that Islamic shari' $a b$ can easily serve as the only law for the society, others have dedicated themselves to exploring ethical values embodied in Islam, and to proving that these Islamic ethics are compatible with modernity - particularly with the modern idea of human rights - without having to apply the shari'ab in any formal sense.

The approaches to human rights developing among Indonesian Muslim intellectuals and activists can be generally classified into two distinct poles. The first is in complete accord with the principles of human rights as formulated in the universal declaration of human rights. The second, on the other hand, exemplifies the resistance of some Muslim intellectuals to the universal declaration of human rights, on the understanding that Islam already encompasses human rights values. ${ }^{3}$ Each group has its own arguments based on its own interpretation of Islamic values and the universal declaration of human rights.

This paper argues for its part that supposed universal human rights are not absolutely universal, and that it is reasonable to question

${ }^{3}$ Besides these two poles, according to Hikam, there is "the state's own interpretation of human rights principles in accordance with national interests;" Hikam, "Islam and Human Rights", p. 2. 
their universality. Since these so-called universal human rights can be shown to be, historically, the product of Western experiences, they therefore reflect a set of Western values, structures, ethics and morality - in short, values of Western secularism. Even some Western scholars are prepared to admit that universal human rights are "a western construct with limited applicability." "The idea of universalizing human rights can be said to be the result of the hegemonic relationship that exists between the West and the East. This cultural hegemony in fact seems to be the continuance of a Western dominance in ideology, politics, economics, military matters and technology over the rest of the world - particularly the Muslim world.

Much of what constitute human rights is in effect individual rights that evolved from European modern thought on natural law. Western countries elevated these rights to legal institutional standards. Through the Universal Declaration of Human Rights, issued by the United Nations in 1948, and the International Covenants of 1966, which went into force in 1976, these rights have now become international law. These bring us to the discussion of the rule of law, as rights can only be institutionalized in a legal context. Accordingly, human rights cannot be separated from democracy and the rule of law, since they are intrinsically interrelated. ${ }^{5}$ In addition, the human rights issue developed as a political response to the emergence of the modern state. But because the idea of the modern state emerged for the first time in Western Europe, it is natural that the philosophical underpinnings of the Universal declaration should have been Western in their genesis. It has nevertheless been argued that the idea of the nation-state as a modern invention was initially foreign to all cultural systems, including the West itself. ${ }^{6}$

${ }^{4}$ Heiner Bielefeldt, "Muslim Voices in the Human Rights Debate", Human Rights Quarterly 17, 4 (1995), p. 593.

${ }^{5}$ See Bassam Tibi, "Islamic Law/Shari‘a, Human Rights, Universal Morality and International Relations”, Human Rights Quarterly 16, 2 (May, 1994), pp. 277-299.

${ }^{6}$ See Reza Afshari, "An Essay on Islamic Cultural Relativism in the Discourse of Human Rights", Human Rights Quarterly 16, 2 (May, 1994), pp. 235-276. 
In order to discern whether the issue of human rights currently under discussion in Indonesia is tending towards either a universalistic or relativist standpoint, the present report focuses on how Indonesian Muslim intellectuals conceive of human rights and how they set out to unravel conflicts between so-called universal human rights and Islamic values as they perceive the two. Specifically, the report focuses on four principal issues in human rights discourse: freedom of opinion, religious freedoms, rights of women, and criminal law -issues which can be regarded as the key elements of human rights discourse.

\section{B. Islam and Human Rights: Distinctive Features and Common Ground}

As generally conceived, Indonesia is characterized by at least two important phenomena. First, it is home to the world's largest national Muslim population; and thus it belongs to the Islamic Conference Organization (ICO), whose members include all countries whose rule is based on Islamic ideology or which contain significant Muslim populations. Second, it is considered a developing country, and can therefore be said to suffer from economic backwardness. These two features seem to have led some Western scholars to conclude that concepts such as democracy and human rights are foreign to Indonesia. The fact that Islam is the religion of the majority leads many to regard the society as incompatible with such modern notions. Furthermore, as a developing country, Indonesia is automatically assumed to be under authoritarian rule. Some would even see, despite the lack of evidence, an intrinsic relationship between Islam and authoritarian rule, and take it for granted that Indonesia, as a Muslim country and a developing nation, has built-in constraints that will prevent it from ever implementing democracy and human rights.

Many Indonesian intellectuals have endeavored to prove that this stereotype has no validity. They have also made various attempts to accommodate the need for democracy and to implement democratic values - particularly the idea of human rights. Human rights should be institutionally protected. Human rights are not only a set of values expressed in either religious or secular culture, but also a set of rights 
regulated by law, government and all forms of social institutions. ${ }^{7}$

Adnan Buyung Nasution, an influential human rights advocate, holds an interesting viewpoint regarding the relationship between Islam and human rights. Although he promotes that universal human rights be implemented in Indonesia without reservation, he fairly points out that Islam already contains the fundamental principles of human rights. Islam as a religion was revealed in an Arab society wherein human rights were not respected; Muslim historians have shown that the coming of Muhammad as the Prophet meant the liberation of mankind from every form of human rights violation. By eliminating Jâhili traditions, which legitimized slavery as well as racial and gender discrimination, Islam provided a strong foundation for society, and contributed to the development of human rights principles. It is even recorded that Islam pioneered the abolition of slavery and discrimination towards women as a consequence of its liberating doctrines. ${ }^{8}$ The international community expects from the Muslim world such contributions for the protection of human rights everywhere.

Likewise, Adnan Buyung Nasution appreciates the efforts that have been carried out by Muslim experts, scholars, leaders and intellectuals - particularly since their meeting in Abu Dhabi in 1977 which resulted in what is called the "Islamic Universal Declaration of Human Rights" (IUDHR). These principles of human rights can serve as a reference for other countries in implementing the protection of human rights in everyday life. Nasution insists, however, that the formulation of human rights not be understood in the particularistic terms expressed in the memorandum on Islamic Human Rights issued

7 These attempts have resulted in the establishment of the National Commission on Human Rights in 1993 with the President's decision, and in later developments the decision was substituted by Law Number 39/1999 on Human Rights, which strengthens the mandate and role of the National Commission. Many prominent figures have once been members of this commission - some of whom can be said to have represented the Muslim community, such as Nurcholish Madjid, an outstanding Muslim scholar, and Munawir Sjadzali, a former Minister of Religious Affairs.

8 Adnan Buyung Nasution, "Hak Asasi Manusia dalam Masyarakat Islam dan Barat", in M. Natsir Tamara \& Elza Peldi Taher (eds.), Agama dan Dialog antar Peradaban, (Jakarta: Paramadina, 1996), p. 110. 
by the Islamic Conference Organization. ${ }^{9}$

Nonetheless, a careful scrutiny of these two documents will lead us to conclude that there is no fundamental difference between the principles expressed in IUDHR and in those codified by the UN (UDHR). The only differences lie in areas concerned with inter-religious marriage, riddah (apostasy), and the right to change religion; the first two of which are prohibited by the ICO memorandum, the third prohibited by the IUDHR, and all three of which are guaranteed by the UDHR of the UN. However, the existence of these prohibitions which are based entirely on religious conviction - does not necessarily mean that Islam has a different understanding of human rights. Nor should it be concluded that Islamic schemes are inferior to the UDHR, as both Islam and the UDHR consist of rights inherent in human beings, which are also God's blessing. Adnan Buyung Nasution asserts that human rights constitute a formulation of fundamental rights inherent in every human. Differences of cultural and historical background among nations certainly do not imply differences in human rights as such; for whatever the differences that exist in society, individuals need protection of their rights. Fundamental human rights do not become universal when those rights are not compatible with the trends of human nature as exhibited by human beings - a proof that the concept of universal human rights is identical with human nature everywhere. ${ }^{10}$

However, Adnan Buyung Nasution, according to Ramage, falls into the camp of secular-Muslim intellectuals, and was once skeptical of Islam. He has, moreover, maintained that Islam in Indonesia, along with military domination, can constitute a serious threat to the idea of democracy and universal human rights. He argues that a fundamentally religious state places greater constraints on the implementation of democracy and human rights than a military-dominated state ${ }^{11}$ - this despite the fact that, at the present time, the military can be said to represent a greater threat to the nation than political Islam. Nasution

${ }^{9}$ Ibid., p. 111.

${ }^{10}$ Ibid., p. 112.

${ }^{11}$ See Douglas E. Ramage, Politics in Indonesia: Democracy, Islam and the Ideology of Tolerance (London, New York: Routledge, 1995). 
claims that many Islamic institutions such as Ikatan Cendekiawan Muslim se-Indonesia (ICMI, the Association of Indonesian Muslim Intellectuals) have weakened the process of democratization. By using religious symbols to establish Islamic solidarity, ICMI unconsciously undermines the prospects for democracy as well as human rights.

Views on human rights have also been elaborated by Muslim thinkers of previous generations, one of them being the late Hasbi ash-Shiddieqy, a leading Muslim scholar of the 1970's. During his time as a member of the Konstituante representing the Masyumi (Islamic party), ash-Shiddieqy invoked the Islamic principles of human rights and recommended that they be included in the draft of the new constitution. ${ }^{12}$ He himself documented his views on human rights as propounded in the Konstituante debates, where he explored five fundamental principles of human rights in Islam. These include: (a) rights of life and personal security, as well as for protection of self, honor, and property (here basing himself on the rights of life and protection of household and family described in the Qur'an (Q.24: 2728); (b) the rights of religious freedom and of adhering to a certain faith, since everyone must respect the rights of others to embrace whatever religion or faith they choose (based on a notion expressed in Q.10: 99, mainly that nobody has the right to impose a religion on other people); (c) the inalienable right to own property, so that property can play its assigned social function (Q.4: 2, 32); (d) the rights of choosing appropriate work, freedom in choosing that work, and receiving a just wage in order to guarantee the prosperity of the family; and (e) the rights of freedom of thought, freedom of expression, and freedom to obtain a better education. ${ }^{13}$

Harun Nasution, a "rationalist Muslim thinker," maintains on the other hand that human rights and freedoms that prioritize individualism are not truly relevant to Islamic concepts of human rights

\footnotetext{
${ }^{12}$ See Ahmad Syafi'i Ma'arif, Islam dan Masalab Kenegaraan (Jakarta: LP3ES, 1985).

${ }^{13}$ See Teungku Muhammad Hasbi ash-Shiddieqy, Islam dan HAM [Hak Asasi Manusia]: Dokumen Politik Pokok-pokok Pikiran Partai Islam dalam Sidang Konstituante 5 Februari 1958, re-edited by Fuad Hasbi ash-Shiddieqy (Semarang: Pustaka Rizki Putra, 1999), 7, 36-79. The most important feature of this document is that ash-Shiddieqy backs every single position with verses from the Qur'an.
} 
and freedoms, which are based on tawhid. Nasution recognizes that Western human rights, conceptually speaking, are based on FrenchRevolutionary ideals of "freedom, equality and fraternity." Nevertheless, he conceives that the philosophical foundations of human rights in Islam are to be found in the doctrine of tawhid. In Islam, tawhid is strongly maintained in the sense that it is only Allah who created the universe. This implies equality and brotherhood among human beings, and even brotherhood among others of God's creatures. Islam not only teaches humanitarianism, but also extends protection to animals and encourages conserving the environment. From these principles of equality, brotherhood and freedom other human freedoms develop such as freedom from slavery, religious freedom, freedom of speech, freedom of will, freedom from fear, and so on. Human rights in turn have their origin in these freedoms, such as the rights to life, prosperity, education, speech and employment. ${ }^{14}$ Human rights are therefore those rights embodied naturally in every created (human) being, each of whom is granted a moral and legal guarantee to enjoy freedom from exploitation, violence, robbery, injustice or other unjust treatments that prevent humans from living properly as the exalted creatures of God.

Islam's position in relation to the human rights discourse is also addressed by other contemporary Muslim intellectuals. Nurcholish Madjid (a leading Muslim scholar and once a member of the National Commission of Human Rights) and Masdar Mas'udi (a young Muslim intellectual) should be mentioned in this regard. Madjid states that Islam recognizes individual as well as social rights. Individual rights result in social responsibility for the sake of society's welfare, while social rights entail individual responsibility towards society. Therefore, rights and duties are the two sides of human dignity. ${ }^{15}$ Madjid basically observes a compatibility of Islamic values with modernity, including issues of human rights and democracy. Having referred back to

${ }^{14}$ Harun Nasution, "Pengantar", in Harun Nasution and Bahtiar Effendy (eds.), Hak-hak. Asasi Manusia dalam Islam (Jakarta: Pustaka Firdaus and Yayasan Obor Indonesia, 1987), pp. vi-xi.

${ }^{15}$ Nurcholish Madjid, "Kaum Muslimin dan Partisipasi Politik: Masalah HakHak Individual dan Sosial yang Tak Terinkari”, in Nurcholish Madjid, Islam, Doktrin, dan Peradaban (Jakarta: Paramadina, 1992), p. 563. 
traditional Islamic literature, Masdar Mas'udi argues that there are at least five fundamental human rights that should be protected: the right to life (bif al al-hayäh); the right to religious freedom (bif al-din); the right to freedom of expression ( al-māh); and the right to have children or offspring (bif.. al-nash). ${ }^{16}$

According to Amien Rais, as quoted by Abdillah, Islam highly respects human rights and regards freedom of thought as the most important right. Freedom of thought is at the root of other rights and freedoms that should be protected in a democratic political system, such as religious freedom, freedom of speech, freedom of association, freedom of opinion, and so forth. In Rais' understanding, Islam provides the freedom to choose, and the example of Adam in breaking his agreement may have symbolized the freedom to choose. Islam even allows an individual to become an atheist as long as he does not harm the public order. ${ }^{17}$

The notion of human rights in Islam as presented in the Qur'an and Sunnah is concerned with the aims, duties and status of human beings in this world. To facilitate these human functions, Islam has provided fundamental teachings that govern the relations of humans with God, other human beings, and the universe and that define the doctrinal scope of the rights and obligations of individuals and societies in both the spiritual and material dimensions. This framework is shaped on the basis of values that differentiate the good from the bad. Therefore, it is on the basis of the good that the foundations needed by humans are established. With regard to human rights, Islam emphasizes the idea of obligations more than rights. The philosophical ground of this emphasis lies in the understanding that the obligation laid on individuals to perform good will automatically bring about rights for others, while those obligations completed by others will result in rights for oneself; therefore, the fundamental teaching of doing good always precedes the prohibition against doing bad (al-amr bi'-ma'rüf wa'-naby 'an al-munkar).

${ }^{16}$ Masdar Mas'udi, Islam dan Hak-hak Reproduksi Perempuan (Bandung: Mizan, 1997), p. 34.

${ }^{17}$ Masykuri Abdillah, Demokrasi di Persimpangan Makna (Jogjakarta: Tiara Wacana, 1999), p. 140. 
The foundation of Islamic values concerning human rights in practice can be understood contextually by taking the existing situations into account. This understanding accordingly not only raises a different color from some aspects which are emphasized but also creates institutional diversity that supports the implementation of human rights. In the post-industrial context, reinterpreting human rights can offer the possibility of developing a new paradigm that views humans as part of a harmonious natural framework. This paradigm can be seen as an alternative to the mechanical paradigm (which implies exploitation of humans and nature) and which today constitutes the model for modern world development, including development in Indonesia.

It can briefly be stated that the principles governing human rights in Islam include: (a) the principle of equality between humans, i.e. that all humans are the same before God with no exception (all are responsible to God only), nor is there any race superior to the other, since all human beings originated from the same ancestor and are thus siblings to one another; (b) the principle of personal freedom, hence the prohibition of human slavery and the obligation of freeing slaves (al-Baqarah, Q.2: 177); (c) the principle of human security, meaning that whoever maintains the life of a human maintains the lives of all humans (al-Mâ'idah, Q.5: 32, and it is also narrated that the fourth caliph, 'A I ibn Abi Țâlib, asserted that the blood of non-Muslims (dhimmis) is as pure as the blood of a Muslim, and that their property is to be protected like that of Muslims); and (d) the principle of justice, a fundamental right of all humans that is emphasized in the Qur'an (al-Shūrā, Q.15; al-A'rāf, Q.7: 29; and al-Hadid, Q.57: 25) but also an obligation in that one is obliged to serve as a witness for the sake of truth (just as God condemns those who give false information when witnessing). ${ }^{18}$

${ }^{18}$ For further explanations of the fundamental rights prescribed in the Qur'an, see Riffat Hassan, "Religious Human Rights and the Qur'an", Emory International Law Review 10, 1 (Spring, 1996), p. 85-96. 
Ahmad Nur Fuad, et al.

\section{Human Rights Discourse during the Konstituante}

Efforts to construct a legal framework of "Islamic human rights" have been made by Indonesian politicians and can be traced back to human rights debates among the members of the Konstituante during the period 1956-59. This fact plainly shows that Indonesian politicians of different ideologies had been engaged with such a crucial issue as human rights at that time, and this was presumably in response to the universal human rights promulgated by the United Nations in 1948.

The assembly debates focused in particular on fundamental issues facing this newly independent state, including its ideological basis, its system of government and the whole structure of the state in general. Debates on crucial points, however, eventually polarized members into at least three important groups: nationalists, Islamists, and socialists; which finally crystallized into two contrasting blocks: the Islamist and the secularist. ${ }^{19}$

Each group proposed their ideological standpoints together with their arguments. As the Konstituante could not agree in the first instance on the basis of the state (having been presented with two alternatives, Islam or Pancasila -five basic principles as the state ideology), it went on to discuss other crucial points, such as human rights. The 1945 Constitution had been described as lacking provisions on human rights, a fact that was made more apparent when the Universal Declaration of Human Rights was formally declared in 1948. Therefore, the Konstituante managed to respond very quickly to the necessity of drafting human rights for the state Constitution.

${ }^{19}$ For a more detailed discussion of debates concerning the ideology of the state, see Ma'arif, Islam dan Masalab Kenegaraan; and for a more comprehensive account and detailed information regarding debates on human rights, see Adnan Buyung Nasution, Aspirasi Pemerintahan Konstitusional di Indonesia: Studi Sosio-Legal atas Konstituante 1956-1959 (Jakarta: Grafiti, 1995). This last-mentioned book by Nasution is a translation of his Ph.D. dissertation submitted to Rijksuniversiteit, Utrecht in 1992, entitled "The Aspiration for Constitutional Government in Indonesia: A SocioLegal Study of the Indonesian Konstituante 1956-1959.” Here, Nasution has recorded the chronology, subjects and even the course of the debate on human rights, using the assembly notes (risalab) as sources. 
Almost all of the political parties in the assembly agreed with each other on the necessity for the protection of human rights in the Constitution. They discussed a large number of issues in connection to this and, as Nasution observes, they expressed different points of view on whether human rights are universal or particular. One viewpoint held that human rights are universal, fundamental freedoms, while others characterized human rights as a means of opposing fascism, chauvinism and militarism; the Muslim representatives, for their part, perceiving human rights from the Islamic shari' ah perspective. The Konstituante seemed to take the Universal Declaration of Human Rights of 1948 as a reference, and the opinions that emerged in the debate might be said to have represented ideas either in line with or in contrast to universal human rights. ${ }^{20}$

Although all parties in the Konstituante agreed on the importance of human rights, they disagreed on three crucial points: (a) the religious justification of human rights; (b) the understanding of human rights as being centered on human beings as individuals; and (c) the acknowledgment of human rights as being worked out by the dynamics of a progressive society. This disagreement was initially provoked by differences regarding the role of religion in the state. For those who saw things from a religious perspective, religion or God had to be the basis for human rights, while for the secularists there were two different standpoints: first, those who saw human rights as individual rights, and second, those who saw human rights as being rooted in the traditions of a particular society.

This debate on the universality and relativity of human rights led the members of the Konstituante to diverse perspectives based on their respective ideologies, with religious freedom being one of the most salient issues dealt with. The Konstituante did manage to achieve complete agreement on the importance of such human rights as religious freedom and freedom of faith; however, the debate on these issues was not free of ideological strife, especially over the question of whether Islam should constitute the official religion of the state. Muslim parties such as the Masyumi and the Nahdatul Ulama (NU) strove to

\footnotetext{
${ }^{20}$ See Nasution, Aspirasi Pemerintahan Konstitusional, pp. 136-146.
} 
promote Islam as the national ideology, and even as the state's religion. Therefore, conflicts and tensions between Islamic and secular parties in elaborating and interpreting the meaning of religious freedom could not be avoided, and this situation had serious implications for the debate over controversial issues: namely separation of state from religion, the prohibition of the propagation of anti-religious views, and freedom from forced religious conversion.

Muslim representatives argued that Islam cannot be separated from the state, and vice versa. The propagation of anti-religious views should therefore be prohibited as it is paradoxical to the very nature of those human rights coming from God. This anti-God or anti-religion propaganda might not only lead to atheistic tendencies but may also give birth to a new religion, such as the religion of Pancasila, and so on. Some Muslim representatives claimed in the course of the debate that Islam deserved to be made the official religion due to its great contribution to independence, and due to the fact that the majority of the population is Muslim. Accordingly, Islam had to occupy a primary role, while other religions were to play a secondary position. Muslim representatives even argued that, although minority religious groups should be protected, their rights should not be the same as those of adherents of the official religion. ${ }^{21}$

\section{Contemporary Discourse}

The discourse of human rights in contemporary Indonesia is developing against a rather different background - that of increasing worldwide demands for implementation of democracy and human rights as the result of globalization and the universalization of value systems, expressed in the provocative works of such influential scholars as Samuel Huntington ${ }^{22}$ and Francis Fukuyama. ${ }^{23}$ Human rights activists in Indonesia, and in particular Muslim intellectuals, can hardly stand

${ }^{21}$ Ibid., pp. 196-197.

${ }^{22}$ Samuel P. Huntington, “The Clash of Civilization”, Foreign Affairs 72, no. 3 (Summer, 1993), pp. 22-49; and Samuel P. Huntington, The Third Wave: Democratization in the Late Twentieth Century (London: University of Oklahoma Press, 1991).

${ }^{23}$ Francis Fukuyama, The End of History and the Last Man (New York: The Free Press, 1992). 
in the way of this tendency towards the universalization of human rights values as the result of ongoing international contacts. Interdependence is a considerable - and unavoidable - feature of international relations, and even initially equal relations may end in an unavoidable hegemony, both politically and culturally. The acceptance of so-called universal human rights, consciously or unconsciously, becomes a necessity, regardless of any reservations felt by Indonesian Muslim intellectuals.

Yet many of the latter are well aware that Islam has promoted universal human values and rights from the very beginning, as can be seen in the "farewell speech" of the Prophet Muhammad. Nurcholish Madjid, for example, argues that these rights and values advocated by Islam and represented by this speech of the Prophet are quite similar to those stated in the Declaration of Independence of the United States. Both documents assert three important points, namely, the importance of life, property and honor. A comparison of some passages from the Prophet's farewell speech and some others from the Declaration of Independence will make this perfectly clear. ${ }^{24}$

The Prophet is reported to have said, while eliciting responses from the crowd: 'What day is this?'

To which they responded: 'The day of sacrifice!'

'What place is this?'

'The holy place!'

'What month is this?'

'The holy month!'

'This is the day of the great pilgrimage. Your lifeblood, property and honor are sacred, as is this place on this day of this month. Have I made (my message) clear?'

'Yes!'

'O God, be my witness!' ${ }^{25}$

Almost in the same vein, the Declaration of Independence includes the statement 'that all men are created equal, that they are endowed by their Creator with certain inalienable rights, that among

${ }^{24}$ From an interview with Nurcholish Madjid, in Surabaya (25 May 2003).

${ }^{25}$ Ibn Sacd, Tabaqat II (1), p. 132. Quoted from Maxime Rodinson, Mohammed (London: Penguin Books, 1971), p. 285. 
these are life, property and pursuit of happiness.' Madjid then asserts that the United States, despite its comparatively secular character today, was founded on metaphysical foundations almost the same as those constituting the Islamic principles of human rights. ${ }^{26}$ Madjid states that Thomas Jefferson, although he rejected formal religions like Christianity, was a Unitarian, a theist and a universalist. Therefore, despite its secular nature, American society admits the metaphysical values represented in the declaration. A shari ab-minded intellectual and activist, Eggi Sudjana, also recognizes similarities between Islam and the Universal Declaration on the topic of human honor. The UDHR reads: "all men are born free and equal in their dignity and rights ...", values also promoted in the Qur'ann (al-Hujurāt, Q.49: 12-13). ${ }^{27}$

In the Indonesian context, where Islam is the religion of the majority, the difference in understanding and applying human rights revolves around the concept and limits of freedom - on which Islam, in Abdillah's view, places so many more restrictions than does the West. However, equality in rights and responsibility among citizens must be emphasized regardless of religion and ethnic background. ${ }^{28}$ For example, living together out of matrimony in the West is a right of every individual, but such is not the case in Islam. In Indonesia, for instance, the police are permitted - even obliged - to take action against any two people who commit adultery, whereas in the West they would be accused of violating human rights should they intervene.

Abdillah admits the universality of human rights, although for him its application cannot be separated from religious and cultural contexts. Differences in the application of human rights in the West and in Muslim countries such as Indonesia are unavoidable, since Islam and the West have different social values and different philosophical bases. However, this does not mean that the two worlds must collide over the application of human rights.

\footnotetext{
${ }^{26}$ Ibid.

${ }^{27}$ See also Eggi Sudjana, HAM dalam Perspektif Islam: Mencari Universalitas HAM bagi Tatanan Modernitas yang Hakiki (Jakarta: Nuansa Madani, 2002), pp. 105-106.

${ }^{28}$ From an interview with Masykuri Abdillah, in Jakarta, April 2003. See also his article, "Agama dan Hak-Hak Asasi Manusia", Media Sunda Kelapa (2002), p. 21.
} 
It is probable that the Universal Declaration arose out of a secular view of human beings, a relativist view of humanity, and views voiced by existentialism. These views seem clearly to influence human rights formulation, and serve as a strong foundation for its documentation. This has been so since human rights arose from the ethos of struggle against a totalitarian worldview and ideology. Human rights documents first began to appear after the Second World War, and we know that before that time European society was dominated by totalitarianism. Human beings were seen as a totality subject to the will and interest of the sovereign power (within systems such as Communism, Nazism and Fascism), in which the rights of individuals were denied. It was in opposition to this that the concept of universal human rights developed. Therefore, human beings are defined in the UDHR as individuals, and this can be said to be a revolt against collectivism. It is an individualism that coincides with humanism and existentialism. ${ }^{29}$

\section{Freedom of Expression}

It is almost impossible to arrive at a universally accepted definition of freedom, since this concept is open to definition within specific cultural, ideological and even religious boundaries. The problem is most apparent when the demand for freedom in its modern humanistic form spreads among religious as well as secular intellectuals. ${ }^{30}$ This is particularly true of the Islamic context.

Islam does not contravene any form of freedom or civil liberty; however, from a religious point of view, this freedom in Islam essentially begins with servitude to God. Taking this standpoint into account, it can be inferred that the interpretation of freedom evolves within the realm of the shari' $a$ h and Islamic values. In Islamic belief, freedom of expression does not extend to the freedom to corrupt, for example. This is so because the purpose of religion is to guide human beings to perfection. Even though freedom of expression is often said to be one

${ }^{29}$ From an interview with Masdar F. Mas'udi, April 2003, in Jakarta.

${ }^{30}$ Shahriar Zarshenaz, Inside in Iran: A Special Survey, Index on Censorship, March, 1992, p. 10; as quoted by Ann Elizabeth Mayer, "Universal versus Islamic Human Rights: A Clash of Cultures or A Clash with a Construct?", Michigan Journal of International Law, vol.15, 307 (Winter, 1994), p. 317. 
of the most fundamental civil liberties, and the product of a long process of western philosophical and political discourse, it needs to be acknowledged that the concept was already conceived and respected by other societies. Almost all major cultural traditions and societies in the world today, including Muslim ones, acknowledge and implement this freedom of expression as a universal human right.

In Indonesia, freedom of expression and association, although guaranteed by the Constitution, is problematical in practice. This freedom seems to be a luxury item that not everybody can acquire, a fact particularly evident during the New Order period, when the government gave priority to political stability, economic development and national security. This development-oriented policy was often supported by military power, and frequently attended by the repression of any dissenting view and movement. Having decided to prioritize economic growth in the early 1980s, the government imposed Pancasila as the only legal basis for social and political organizations. No political party or even religious organization was permitted to make use of Islam as its basis or ideology. Moreover, the ruling elite established an official interpretation of the Pancasila to a degree that any other interpretation by political or religious leaders was dismissed as false and dissenting, and thus as a threat to political stability and national integrity.

The New Order government managed to restrict the freedom of citizens to express their political ideologies and preferences. It seemed that there was to be no room for differences with government policy, no room for political dissent. This repressive policy was challenged, on the one hand, by human rights activists on the basis of universal principles of human rights, and on the other by Muslim leaders on the basis of religious doctrine. The response to this challenge, however, was severely repressive: the government jailed activists and leaders who challenged its authority, or at least scrutinized their movements or statements. More particular in this regard was the government's policy toward Islam in general - and Islamist groups in particular - to the extent that it began to regard Islam as a most dangerous threat to political authority. 
In such a political atmosphere, many Muslim intellectuals who advocated human rights came under increasing pressure from the state apparatus and, astonishingly, from some Islamist groups as well. Their voices were muted and suppressed by censorship or harassment, making it difficult for them to participate openly in the discourse and activities aimed at promoting human rights in Indonesia. There were still, of course, Muslim scholars such as Nurcholish Madjid, who dared to express their views and challenge the relativist vision of human rights articulated by the state and the Islamists, but their path was not made easy.

The New Order government often claimed that violations of freedom of expression and other human rights could be tolerated in the name of the overriding interests of national unity, political stability and economic development. When human rights activists attempted to contest the government by enlisting the support of their cultural and religious traditions, they found that those resources too were being manipulated by a ruling elite who sought to rationalize human rights limitations for the sake of protecting culture and religion itself. Political stability and economic development, however, can never be promoted by or sustained through the violation of freedom of expression and other human rights. Culture and religion are in fact sustained and promoted by the protection of freedom of expression, not by its violation.

The essence of freedom of expression and freedom of association is intrinsically related to the idea of democracy in general. Democracy protects the rights and liberties of people and recognizes the freedom of people to express their views. This right renders plausible the idea of opposition. However, the "will of the people" is very frequently plural, and democratic traditions provide many different ways of defining and managing opposition. The principles of democracy clearly guarantee the rights of individuals and groups to disagree with the government, although they also leave room for certain reservations as to such disagreement. For despite the fact that many definitions of democracy recognize the right and even the necessity of opposition parties to exist, the term "partisan politics" carries negative connotations. This is particularly true when seen in the context of the 
need for multiparty competition. Practically, political opposition can take a variety of forms, ranging from revolutionary advocacy to the destruction of the existing system and to varying levels of disagreement with the people in power in a political system. ${ }^{31}$ The lack of democracy and the absence of freedom of expression have provided no opportunity for formal opposition parties to appear, not only under the New Order government, but even during the recent phase of transition to democracy.

The increasing demand for the right of freedom of expression and association has its legal and political underpinnings in almost all declarations of human rights. The Universal Declaration of Human Rights states that "everyone has the right to freedom of opinion and expression; this right includes freedom to hold opinions without interference and to seek, receive and impart information and ideas through any media and regardless of frontiers" (article 19). Moreover, it is stated that "everyone has the right to freedom of peaceful assembly and association," and "no one may be compelled to belong to an association" (article 20).

In light of this, it should be kept in mind that freedom of expression is not concerned only with private individuals: it also is essential to the evolution of public discourse in a civil society. ${ }^{32}$ It has already been pointed out that the concept of individual human rights reflects a cultural morality that originated in Europe. This concept germinated from notions of natural law and has been related to a sociocultural process of individuation that occurred in the wake of modern developments in the Western milieu. Therefore, another perspective in this case that of a developing country - maintains that the project to universalize freedom of expression and other human rights ought to take into consideration cultural, religious and even geopolitical realities. It is important to promote consensus on the concept, content and implementation of this right of freedom of expression. Supporters of this perspective would argue that it is important and useful "to speak

${ }^{31}$ John L. Esposito and John O. Voll, Islam and Democracy (New York: Oxford University Press, 1996), p. 34.

${ }^{32}$ Bielefeldt, "Muslim Voices”, p. 591. 
of freedom of expression as a universal human right, but in the sense of a project to be constructed through global collaboration and not as a predetermined concept and accomplished fact." ${ }^{33}$

Therefore, it is hardly astonishing that with certain reservations the Cairo Declaration (CD) takes almost the same standpoint on this right of freedom of expression. Article 22 of the CD states that (a) everyone shall have the right to express his opinion freely in such a manner as would not be contrary to the principles of the shari ${ }^{-1} a$; ; and that (b) everyone shall have the right to advocate what is right, propagate what is good, and fight against what is wrong and evil according to the norms of the shari'ah.

In Indonesia, where memories of the crackdown on freedom of expression under the New Order government are fresh, the Indonesian Law 39/1999 on Human Rights (ILHR) makes a point of including these basic individual rights. Article 23 states that every person has the freedom to choose and hold his/her political conviction; and that everyone has the freedom to hold, advocate and disseminate opinions according to his/her conscience, whether oral or written, through the mass- and electronic media, while always taking into consideration religious values, morality, order, public interest and national integrity. In addition, article 24 states that everyone has the right to gather, meet and associate for peaceful purposes. Every citizen or group in society has the right to establish a political party, non-governmental organization or other organization and to participate in government and governance for the sake of the protection, enforcement and advocation of human rights, in accordance with the law and the constitution. Article 25 even provides the guarantee that everyone has the right to advocate opinions in public, including the right to strike, again in accordance with the law and constitution.

Article 43 of the Indonesian Law of Human Rights states that every citizen has right to be elected and to elect another in a general

${ }^{33}$ In this respect, freedom of expression should be perceived " not only in the negative sense of absence of official restraints for individual persons to express themselves in political, artistic, literary, scholarly and other ways, but also to include affirmative positive action to enable inarticulate individual and collective social and cultural forms of self-expression." 
election based on the equality of rights through direct, free, confidential, fair and just means, according to the law; similarly, every citizen has right to participate in governance directly or through duly elected representatives in conformity with the manner prescribed by law.

The drafting of these fundamental rights (all of which are included in the UDHR) into the Indonesian Law on Human Rights indicates that Indonesia has made significant progress in the human rights field, at least as regards the legal framework. Despite the fact that, on a practical level, there is still the suppression of opinions different from those of the government and even restrictions on the activities of some social groups, this law serves as an essential instrument for the enforcement of human rights in Indonesia.

In the viewpoint of certain Muslim intellectuals, freedom of expression as an individual right can hardly be isolated from the idea of political participation. Nurcholish Madjid, for example, argues that, from a religious point of view, the considerable role assigned to political participation by Islam has deep roots in the existence of individual and social rights to which all human beings are entitled. This is because individual rights in society engender a common social responsibility towards the welfare of all citizens, while the rights of society generate the responsibility of individuals to society. Thus, rights and responsibilities are indeed two sides of a single human reality, i.e., dignity and honor. Komaruddin Hidayat maintains that "the highest right in Islam is freedom, freedom in choosing the right or the wrong path (fa-man shä'a fa'l-yu'min wa-man shä'a fa'l-yakfur), as asserted by the Qur'an." ${ }^{34}$ This is so because God regards human beings as uniquely elevated in terms of honor and dignity. In social life, however, one's freedom is limited by the freedom of others (burriyat al-mar'i maḥdüdah bi-hurriyyat ghayrib).

In light of this, the rights that constitute personal freedom are what human beings need to assure their dignity, while carrying out the obligations essential to their sense of honor. Those individual rights that cannot be denied are rooted in the principle that, in the last instance, human responsibility to God in the Hereafter is fully that of

\footnotetext{
${ }^{34}$ From an interview with Komaruddin Hidayat, 23 May 2003, in Jakarta.
} 
the individual. ${ }^{35}$ Madjid maintains that a system of society can be said to be democratic only when the opportunity is open to each individual or group of individuals in society to express their opinions freely and participate therein however they choose. No single element in society should be allowed to dominate the rest. Accordingly, this will produce a system that contains within itself a mechanism of checks and balances, and that encourages the growth and development of better social and political conditions.

The right to freedom of expression and opinion in Islam has, in addition to doctrinal underpinnings, certain historical foundations, and encompasses all human affairs, ranging from the realm of family to the governance of state. Baharuddin Lopa, once a leading attorney and a Secretary General of the National Commission of Human Rights and Minister of Justice and Human Rights under Abdurrahman Wahid's administration, contends that this principle was originally observed by the Prophet, who thereby accommodated the opinions of his companions regarding politics and war. ${ }^{36}$ Lopa posits that freedom of thought, expression and opinion is a freedom granted to humans at birth. It is this freedom that, in the course of human development, has generated the many intellectuals and even statesmen who have taken responsibility for the safety and welfare of their fellow citizens. Consequently, they must be careful to respect the right of these citizens to freedom of expression, thus implying a readiness to be criticized and opposed. ${ }^{37}$

It is worthy of note, however, that the right to freely express ideas and opinions is guaranteed by Islam. Muslims are obliged to express their ideas concerning morality, public interest and common law, as confirmed in the doctrine of al-amr bi'l-ma'rüf wa'l-naby 'an almunkar. However, this freedom must be confined to virtuous speech, since Islam prohibits its adherents from speaking evil lest this generate enmity among members of society. ${ }^{38}$

\footnotetext{
${ }^{35}$ Madjid, “Kaum Muslimin”, pp. 562-563.

${ }^{36}$ Baharuddin Lopa, al-Qur'an dan Hak-Hak Asasi Manusia (Jakarta: Dana Bhakti Prima Yasa, 1996), p. 45.

${ }^{37}$ Ibid., p. 47.

${ }^{38}$ ash-Shiddieqy, Islam dan HAM, pp. 81-82.
} 
Ahmad Nur Fuad, et al.

\section{Religious Freedom}

The right of religious freedom is also recognized as a fundamental human right. Religion is said to exist on a metaphysical level; therefore, there is none who has the right to impose a certain religion or faith on others. Madjid even argues that the freedom to choose and decide faith or religion is the most fundamental human right. Therefore, religion cannot be imposed, as this will negate the very value of faith itself. Each individual must choose his faith freely and take full responsibility for all risks and consequences. For this, human beings have been provided with the ability to recognize truth from falsehood, good from bad (fitrah). ${ }^{39}$ It must be added in this respect that religious freedom or liberty entails not only the right of individuals to possess and express their personal beliefs, but also encompasses the right to worship together and to organize religious communities independent of government interference. ${ }^{40}$

If such a right does not exist in a particular state, its citizens should strive for it, since rights are won, not given. Political theory, after all, holds that no state will voluntarily concede to citizens their rights, for granting such rights will mean a decrease in its power; and struggling for fundamental individual rights (such as religious freedom) is one of the forms of socio-political participation that is most important in a society. ${ }^{41}$ Rights are the primordial property of the individual, just as responsibility is a manifestation of the limitations set on these rights by other individuals. ${ }^{42}$

The Qur'anic proclamation in al-Baqarah (Q.2: 256) stating that "there shall be no coercion in matters of faith" guarantees freedom of religion and worship. This means that, according to Qur'anic teaching, non-Muslims living in Muslim territories should have the freedom to

\footnotetext{
${ }^{39}$ Madjid, "Kaum Muslim”, p. 564.

${ }^{40}$ Bielefeldt, “Muslim Voices”, p. 591.

${ }^{41}$ Madjid, "Kaum Muslim”, p. 565.

${ }^{42}$ Ibid., p. 567.
} 
follow their own faith-traditions without fear of harassment. ${ }^{43}$ The right to exercise free choice in matters of belief is unambiguously endorsed by the Qur'an in al-Kahf (Q.18: 29), which states: "The truth is from your Lord, let him who will believe, and let him who will reject." ${ }^{44}$ In the context of the human right to exercise religious freedom, it is important to mention that the above dictum from al-Baqarah applies not only to non-Muslims, but also to Muslims. For while those who renounced Islam after professing it and then engaged in "acts of war" against Muslims were to be treated as enemies and aggressors, the Qur'ān does not prescribe any punishment for non-profession or renunciation of faith. The decision regarding a person's ultimate destiny in the Hereafter rests with God. ${ }^{45}$

With regard to religious freedom, Islam asserts the freedom to choose religion; the line between imän (faith in God) and kufr (infidelity) is clear: whoever wants to be a believer (mu'min) shall believe, and whoever wants to be an infidel (kafir), that is his choice, for if God were to so wish, all human beings on this earth would believe (alBaqarah, Q. 2:257; al-Kahf, Q. 18:29; Yūnus, Q. 10:99). The principle of freedom to choose one's religion is also reflected in the attitude of the Prophet Muhammad, who rejected the designs of a Jewish convert to Islam to push his son to convert.

It is believed by Muslims that human beings are the creation of God, Whom they must serve in order to attain happiness in this life and in the Hereafter. In the course of human history, religious life has undergone considerable development, colored by interactions and even tensions between various religious adherents. Article 18 of the UDHR provides the right to adhere to any religion one likes by saying that "everyone has the right to freedom of thought, conscience and religion;

${ }^{43}$ Arguments regarding the right to religious freedom are generally based on Surat al-Baqarah (Q.2: 256): "there shall be no compulsion in religion", although most writers have different opinions regarding religious conversion. See Hassan, "Religious Human Rights", p. 90; and Allahbukhsh K. Brohi, "Human Rights and Duties in Islam: A Philosophic Approach”, in Salem Azzam (ed.), Islam and Contemporary Society, (New York: Longman, 1982), pp. 248-249.

${ }^{44}$ Hassan, "Religious Human Rights", p. 90.

${ }^{45}$ Ibid., p. 91. 
this right includes freedom to change his religion of belief, and freedom, either alone or in community with others and in public or private to manifest his religion or belief in teaching, practice, worship and observance." The International Covenant on Civil and Political Rights (ICCPR), article 18 (1) states: "Everyone shall have the right to freedom of thought, conscience and religion," a formulation identical to that of the UDHR.

However, it can be observed that the Cairo Declaration (CD) provides no guarantee of religious freedom, even though by the standards of international human rights norms, freedom of religion is a fundamental right. ${ }^{46}$ It can be easily comprehended that the standpoint of the $\mathrm{CD}$ is controlled by a particular theological viewpoint based on an interpretation of certain Qur'anic verses. Article 10 of the Cairo Declaration states: "Islam is the religion of unspoiled nature. It is prohibited to exercise any form of compulsion on man or to exploit his poverty or ignorance in order to convert him to another religion or to atheism."

Theoretically, this formulation leaves no room for change of religion or belief (apostasy), while at the same time its failure to provide any guarantee or protection for the exercise of religious freedom may be said to encourage condemnation, violence and persecution. Not only is religious conversion regarded as treachery, but even holding dissenting views on religious matters can easily be regarded as heretical, perhaps even deserving of capital punishment. In certain Muslim countries, this phenomenon coincides with the increasing influence of "Islamic fundamentalism," whose proponents are quick to accuse any Muslim who expresses critical views on religion or who challenges official orthodox doctrines of being apostates. Most of these "apostates" have been put to death, or at least compelled to leave their Muslim homeland and migrate to another country. ${ }^{47}$ The Cairo Declaration's provisions regarding religion make no pretense of neutrality; they are forthright in favoring Islam at the expense of other religions. The declaration assumes that Islam is the true faith and that

\footnotetext{
${ }^{46}$ Mayer, "Universal Versus Islamic Human Rights", p. 333-334.

${ }^{47}$ Mayer, Fundamentalist Impact, pp. 117, 125, 137.
} 
adherence to Islam is natural, with the consequence that it effectively bans other faiths from proselytizing.

Freedom of religion is also recognized in the Indonesian Law of Human Rights as an individual human right. Article 22 (1) states that everyone has freedom to adhere to his/her religion and to worship according to his/her religion or belief, while Article 22 (2) declares that the state guarantees freedom to everyone to adhere to his/her religion and to worship according to his/her religion and belief. This article represents an assertion of the same point stated in article 29 of the 1945 Constitution: "The state is based on the belief in One God (Ketuhanan Yang Maha Esa); and the state guarantees the freedom of every citizen to adhere to his own religion and to perform religious observance according to his religion and faith." 48 The state may introduce regulations concerning religious life in order to harmonize the different existing religious faiths and communities, but it cannot force its citizens to adhere to any particular faith or to observe their religious beliefs and rituals, as the domain of faith is individual. ${ }^{49}$

There are many aspects of religious freedom that need to be considered: the freedom to choose one's religion; the freedom to exchange ideas regarding religious matters; true faith in the religion as the requirement of valid faith; and freedom of ijtibäd. ${ }^{50}$ According to Lopa, however, this freedom of religion does not mean the freedom to have no religion: only the freedom to choose what religion to adopt. He also notes that Article 18 of the UDHR guarantees everyone the right to choose and practice one's religious obligations, whereas Islam does not permit Muslims to convert to other religions (murtadd, apostasy). Lopa provides a Qur'anic verse in support of his view from

${ }^{48}$ Officially, Indonesia acknowledges five religions, namely Islam, Catholicism, Protestantism, Hinduism and Buddhism. Other religions and beliefs such as Confucianism and Baha'ism do exist and develop in the country. Tensions among these religions and their adherents can hardly be avoided in certain cases, as the nature of certain religions is missionary. This phenomenon becomes more problematic when, at certain times, one religion is favored by the state over another, thus generating envy and jealousy.

${ }^{49}$ From an interview with Komaruddin Hidayat, 23 May 2003, in Jakarta.

${ }^{50}$ Lopa, al-Qur'an, pp. 86-87. 
al-Baqarah (Q. 2:218): "And if any of you turn back from their faith and die in unbelief, their works will bear no fruit in this life and in the hereafter; they will be companions of the fire and will abide therein." 51 Apostasy from Islam can be regarded as treachery: consequently, it does not tolerate alteration or change in faith, because this attitude is by no means compatible with the sacred message of Islam.

It is hardly surprising that the issue of religious conversion is so sensitive in Indonesia; after all, many of the religions active in the country are missionary in nature. In an effort to preserve social peace, therefore, the government promulgates laws concerning religious proselytization $\left(d a^{w} w a b\right)$ and the establishment of places for religious worship and observance. ${ }^{52}$

Most interesting in this discourse are the views expounded by Masdar Mas'udi concerning the issue of riddah. In this respect, he even questions the policy of the first caliph, Abu Bakr, to launch wars against those who became apostates: On the basis of what religious justifications, he asks, did Abu Bakr do so? Mas'udi asserts that this policy was inspired by the tendency of exclusivism in the Qur'an and Sunnah. He considers it significant that the doctrine of executing people who change their religion, advocated today mostly by Islamist groups, grew out of an inter-religious experience that was overshadowed by the bitterness of religious conflict. The rights of Muslims became distinguished from the rights of non-Muslims in certain cases, and although their civil rights might have been equal, their respective political rights were widely divergent. ${ }^{53}$

When we observe the articles of the UDHR concerning religious freedom, or even freedom to have no religion (which is often regarded as contradictory to Islam for example), we find no actual difference or contradiction. ${ }^{54}$ In Masdar's view it is true that, according to Islam,

${ }^{51}$ This and all other translations of Qur'anic verses in this article are from A. Yusuf Ali, The Meaning of the Glorious Qur'an (Beirut: Dār al-Kitāb al-Lubnany, 1934).

${ }^{52}$ Lopa, al-Qur'an, pp. 86-87.

${ }^{53}$ Masdar Mas'udi, "Hak Asasi Manusia dalam Islam", in E. Shobirin Nadj and Naning Mardianah (eds.), Diseminasi Hak Asasi Manusia: Perspektif dan Aksi (Jakarta CESDA LP3ES, 2000), p. 70.

${ }^{54}$ From an interview with Masdar F. Mas'udi, April 2003, in Jakarta. 
converts are apostates, but in this case the state authority has no right to control individual faith or religious conversion. He says: "It is not the authority of the state to control such a private right as faith. This does not mean however that when UDHR permits religious conversion, Islam then should do the same. Islam says that those who convert are considered great sinners, and can be accused of being apostates (murtadd). UDHR does not say that conversion is a great sin. Therefore, the two positions cannot be diametrically contrasted." ${ }^{55}$

The fact that the freedom of religious conversion is restricted by Islam is frequently held up by Western scholars as one of the religion's weakest human rights positions, especially when compared to article 18 of the UDHR. ${ }^{56}$ There are, however, differences among Muslim intellectuals regarding the status of Muslims who convert to other religions. According to Islamic law (fiqh), apostates can be sentenced to death, based on the hadith which states that man baddal dinah fa-qtulüh (Kill those who change their religion). However, there are two opinions with respect to this problem. Abdillah observes, for instance, that Muhammad Tahir Azhary, a Muslim scholar of law, agrees with the application of the death penalty for riddah, because Islam has provided individuals with the freedom to choose religion and belief; thus once a person is an adherent of Islam, he should remain Muslim forever, if only to prove that he is not playing with God..$^{57}$ Although it is ambiguous as to whether his description reflects his personal viewpoint, Azhar Basyir likewise regards dissenting from the majority as riddah, which according to the above-cited hadith deserves the death penalty. ${ }^{58}$ This however is only valid in wartime; in a situation of peace, those who convert from Islam should only be advised to return to Islam, without violence, and not sentenced to death. In contrast to Azhary, and going further than Basyir in many respects, Ahmad Syafi'i Ma'arif asserts that it is only God who has the right to punish apostates.

\footnotetext{
${ }^{55}$ Ibid.

${ }^{56}$ See Murad Hoffmann, Islam: The Alternative (Reading: Garnet Publishing, 1993).

${ }^{57}$ Abdillah, Demokrasi di Persimpangan Makna, p. 143.

${ }^{58}$ This Prophetic tradition was reported by al-Bukhāri and Muslim from Ibn Mas'ūd.
} 
Ahmad Nur Fuad, et al.

Human relations are based on the principle of respect, not contempt. Thus, it is the right of an individual to convert as long as this conversion is based on freedom of will..$^{59}$

In this regard, Masykuri Abdillah contends that it is possible for someone to change his religion, since Islam does not prohibit religious conversion. The tradition that obliges the community to kill the apostate, he claims, is a weak one. Nor is there any definite statement in the Qur'an on this point. Rather, as Abdillah says, "the tradition concerning riddah is actually associated with the revolt against the government. Those who convert and then call other people to fight against Muslims are subject to be fought against, and in this case apostasy is associated with the act of revolt (baghy)." ${ }^{60}$ According to Komaruddin Hidayat, riddah (apostasy or religious conversion) is a kind of political dissent or military dissident, since Islam is often seen from a political perspective. Because the caliph regarded apostates as a threat to the nascent Muslim community, conversion came to be treated as a matter of politics rather than one of theology or faith. ${ }^{61}$

The freedom to change religion may also be said to derive from the idea of individuality, which in turn can be regarded as the most important and distinctive feature of human existence. Individuality, not individualism as such, is the primary reality of human kind, while communality is only a secondary one. Man will be responsible for his deeds individually on the Day of Judgment. Therefore, everyone has the right to differ ( haqq al-ikhtilä), not only in expressing opinions, but even in changing one's religion. In this connection it may be of interest to consider the controversy that erupted some years ago in Egypt and Sudan. Farag Fouda, an Egyptian intellectual, was accused of promoting the view that it is the right of an individual to change his belief: for this and other opinions concerning religious freedom he was killed by Egypt's Muslim extremists. Fouda was opposed to their position that freedom of religion, and particularly the right to change religious affiliation, cannot be ratified into legislation for "it goes against

\footnotetext{
${ }^{59}$ Abdillah, Demokerasi di Persimpangan Makna, p. 143.

${ }^{60}$ From an interview with Masykuri Abdillah, April 2003, in Jakarta.

${ }^{61}$ From an interview with Komaruddin Hidayat, 23 May 2003, in Jakarta.
} 
shari'ah, and it is incompatible with the Islamic view of apostasy (riddab)." The extremists argued that the killing of an apostate is permitted since it is a punishment legitimized by the shari ${ }^{6} a{ }^{6}{ }^{62}$

Although there has been no prominent Muslim figure in Indonesia who has converted from Islam to another religion, the controversy over apostasy is still widespread due to the emergence of liberal or secular tendencies in Islamic thought among certain Muslim intellectuals. The situation in Indonesia is rather different, although in some respects it features many similarities with other Muslim countries, such as Sudan and Egypt. In the latter two nations, accusations directed at liberal Muslim thinkers by Islamist groups have led to their deaths. In Indonesia, some Muslim thinkers have been accused of being käfirs (infidels) or murtadds (apostates) due to their secular religious viewpoints. However, local Islamist groups have yet to make an attempt on the lives of even prominent liberal intellectuals, such as Nurcholish Madjid, whose ideas on secularization, for example, are controversial.

The rights of minority religious groups in Indonesia represent another challenge to religious freedom. The issue is a sensitive one, and has even made for tense relations between the existing religions in the country. The tensions usually begin as religious in nature, but then rapidly take on a political significance. Amien Rais, as Abdillah writes, asserts that the rights of minority religious groups to public speech, religion, free will and freedom from fear should be guaranteed fully, including their right to become government ministers or to have positions in state administration. Even now they can obtain the status of special citizens, which exempts them from taking part in the defense of the state. ${ }^{63}$

\section{Rights of Women}

The rights of women (or the idea of gender equity) today forms one of the most fundamental issues in the human rights discourse. In the views of some women's rights activists, so-called Islamic feminism

${ }^{62}$ Jan Henningsson, "Contemporary Understanding of Human Rights in Islam", in The Bulletin of the Henry Martyn Institute of Islamic Studies, vol.14, Nos. 3 \& 4 (July-December 1995), pp. 97-98.

${ }^{63}$ Abdillah, Demokrasi di Persimpangan Makna, p. 120. 
Ahmad Nur Fuad, et al.

is characterized by a consciousness of oppression and repression towards women in society, the workplace and the family, as well as conscious actions by females and males to change the situation using the sacred texts as a foundation. According to this definition, therefore, one cannot be called a feminist if one only recognizes the existence of discrimination on the basis of sex, male domination and patriarchy. Rather, one should actively try to alter the situation. In other words, cognition should be followed by actions to change the system that undermines women. Patriarchy, one of the major problems identified by Muslim feminists, is accordingly seen as being at the root of misogyny. ${ }^{64}$

One of the most salient subjects in the discourse on women rights is the issue of political participation. Basically, the political rights of women in contemporary Islamic discourses (including those in Indonesia) are still controversial, although there has been a shift in perception. There are at least two poles of thinking regarding the role and rights of women in politics: (a) those who would prohibit women from enjoying their political rights; and (b) those who advocate that women have proportional political rights.

The first group argues that the primary duty of women is to concentrate on the domestic sphere, i.e., to maintain the harmony and morality of the family. From a religious and cultural point of view, its members say, women should engage only in household affairs such as taking care of children - social and political affairs are a man's responsibility. The second group asserts that the participation of women in the political sphere cannot be delayed, since there is already an urgency felt to equate the political rights of men and women. ${ }^{65}$

${ }^{64}$ Budhy Munawar-Rachman, Islam Pluralis (Jakarta: Paramadina, 2001), p. 406.

${ }^{65}$ Syafiq Hasyim, Hal-hal yang tak Terpikirkan: Tentang Isu-isu Keperempuanan dalam Islam (Bandung: Mizan, 2001), pp. 195-196. This controversy was particularly apparent prior to the 1999 election, when one of the candidates for presidency was a woman, Megawati Soekarnoputri, now President of Indonesia. Various arguments have been stated, based on religious teachings and interpretations of Islamic law (fiqh) regarding the position and role of women in politics; but certainly most of their reasons for rejecting a woman as president were largely political, rather than merely religious. 
Abdillah for one admits the existence of two streams regarding human rights: one universalistic and the other particularistic. Universal human rights can be interpreted into particularistic human rights. However, we should avoid formulating particular human rights on the basis of political interests, which is what happens when women are prohibited from playing a role in political affairs. In many Arab states, for instance, no accommodation is made for women to take part in politics. This is not right, since there is no such prohibition in Islam.

Women's leadership in the intellectual, socio-political and family domains is another important point of discourse. Much of the discussion involves the controversy over a remarkably unclear prescription in the Qur'an that appears to prohibit women from assuming leadership of the community. The verse in question (from al-Nisāa, (Q. 4: 34)) is, however, remarkable mainly for its potential to be used to justify a repressive patriarchal standpoint and gender-bias. The same verse is used by others to support the domination of the man in the household, a belief that can also be questioned. ${ }^{66}$ The fact remains that political leadership can be exercised by any individual without regard for sex, race or religion, provided he/she has the capability to undertake such responsibility. ${ }^{67}$ Article 49 (1) of Indonesia's Law of Human Rights states that women have the right to elect, to be elected, to be assigned to work, and to follow a profession, according to certain conditions and laws. This article constitutes an assertion that men and women as citizens have equal rights in politics and government, as stated in article $43(1,2,3)$.

If there is a limitation on the rights of women to undertake leadership, this is connected with (among other things) the prohibition against their leaving home without the permission of their husbands. How can a woman justify leaving the concealment of her house? This idea brings us to the issue of a wife's obedience to her husband. It is narrated that, before leaving home for a long period, a husband said to his wife not to go outside the house. In the meantime, the wife received a message that her father was dying, asking her to go see him. But the

\footnotetext{
${ }^{66}$ Mas'udi, Islam dan Hak-hak Reproduksi Perempuan, p. 67.

${ }^{67}$ Ibid., p. 70.
} 
wife chose not to do so out of loyalty to her husband. Mas'udi questions the reliability of this narrative and asserts that it is often understood in the context of male domination over women in almost all human affairs. Obedience, therefore, should be understood more in the sense of reciprocal respect and appreciation between spouses.

Women's rights with respect to marriage are also controversial. According to the Law 1/1974 on marriage, the bond between husband and wife is basically monogamous. However, the possibility of having more than one wife (polygamy) is open to all Muslim men, up to a maximum of four, but only after obtaining permission from the Islamic court; indeed, without such permission, such marriages have no legal significance. Furthermore, permission to have more than one wife can only be given when one of the following conditions occurs: (a) the wife cannot perform her function as wife; (b) the wife has physical handicaps or a disease that cannot be cured; or (c) the wife cannot give birth. In addition, the husband should fulfill the following cumulative conditions: (a) there must be written agreement from the wives; (b) the husband must guarantee that he can afford the needs of so many wives and children; and (c) there must be a written agreement that the husband will treat the wives and children justly and fairly. ${ }^{68}$ This implies that, theoretically, the law tries to regulate the practice to the extent of ensuring that the husband who marries more than one wife must be able to (a) afford economic provisions for wives and children; and (b) give fair treatment to his wives. This also indicates that the law seeks to protect the rights of women, in order that the wives enjoy a just and fair treatment from their husband.

Syafiq Hasyim tries to deconstruct the understanding and practice of polygamy. Quoting 'Abduh, he argues that the permission given by Islam for polygamy has led to the assertion that the religion denies the concepts of democracy and human rights. Polygamy can be seen as a form of discrimination against, and marginalization of, women. Hasyim

${ }^{68}$ Khoiruddin Nasution, Status Wanita di Asia Tenggara: Studi Terhadap Perundangundangan Perkawinan Kontemporer di Indonesia dan Malaysia (Jakarta: INIS, 2002), 107-108, based on Law no.1/1974 article 3; Compilation of Islamic Law article 56-58; and Government Decree no.10/1983 article 10. 
states that the most important thing in this case is not the matter of obtaining permission (mubăhatat), but that of justice ('adalab). If a husband cannot respect the rights of his wife, the structure of the family will be damaged; indeed, the primary core of a family is the existence of reciprocal respect and love among its members. In this case, he places more emphasis on essential and qualitative justice, such as passion, or love, rather than merely on quantitative justice (known to legal experts as qist..$^{69}$

The justice that is most often debated by jurists, however, tends to be qualitative justice, which in Islamic law regulations on polygamy refers to such notions as giving equal provision to all wives. Qualitative justice is more important, and the person who can afford quantitative justice is not always the one who can satisfy the requirements of qualitative justice. ${ }^{70}$ In his treatment of the issue of polygamy, Komaruddin Hidayat likewise distinguishes between al-qist. and al-'adl. He asserts: "Al-qist is a quantitative category, while 'adl or 'adālah is a qualitative one. The first category is concerned with the equal provision of material needs such as money, and this can be afforded by those who have more than one wife. The latter, that is ' $a d l$, is more abstract in measure, and, therefore, it is difficult for people to achieve with regard to polygamy." 71

The rights of women with regard to the relations between husband and wife even extend to the right to propose khul' (asking one's husband for a divorce). This however depends on the decision of an Islamic court. Khul' can be proposed by the wife for several reasons: (a) the husband cannot provide the primary needs such as food, clothing, shelter, health care, etc. (b) the husband suffers from a physical handicap, such as impotence, to the extent that he cannot serve biological needs; (c) the husband treats the wife cruelly, such as by striking, or kicking her; (d) the husband leaves home for long periods, whether on business, or in search of knowledge, etc.; or (e) the husband is put in jail. If the wife is not satisfied based on one of these conditions,

\footnotetext{
${ }^{69}$ Hasyim, Hal-hal yang tak Terpikirkan, p. 159.

${ }^{70}$ Ibid., pp. 161-162.

${ }^{71}$ From an interview with Komaruddin Hidayat, 23 May 2003, in Jakarta.
} 
she has the right to propose $k b u t^{k}$ to the court, and ask her husband to release her from matrimony. ${ }^{72}$

Another important category of women's rights includes those pertaining to her reproductive role. Mas'udi posits that there are three basic rights in this respect: (a) the right of protection of safety and health; (b) the right of support, not only during the vital reproductive processes, but also after that process as a wife and mother of children; and (c) the right to be involved in the decision-making process. ${ }^{73}$

The most important objective of the feminist struggle to promote women's rights is to ensure that a woman achieves equity, dignity, and the freedom to choose and decide how to manage her life and body, both inside and outside the home. Women activists of human rights strive for the establishment of a just social system for both men and women, free of exploitation and of categorization on the basis of class or sexual prejudices. What feminists insist on is an equal and balanced position between male and female as citizens in the public domain, and a complementary state of affairs in the domestic sphere. To achieve this objective, Muslim feminists have critically deconstructed the traditional interpretation of Islamic texts on gender issues. According to one feminist activist, the origins of gender inequity can be traced to a traditional reading of Islamic texts. The agenda of feminist Islam, therefore, is to establish a democratic system that gives women freedom of choice on the basis of fundamental human rights. ${ }^{74}$

\section{Criminal Law}

Although corporal punishments ( $($ u $u \bar{u} d$ ) for committing a criminal act (jarimah) have been prescribed in theory by Indonesian Muslim jurists (based on their interpretation of the Qur'an and the Hadith), in practice they are not applied in Indonesia, since the state does not promulgate these budüd as part of Islamic law, or shari'ah. Rather, the state makes use of secular law. Therefore, there is neither amputation of hands for stealing, nor stoning for adultery, nor even the death penalty for unlawful

\footnotetext{
${ }^{72}$ Mas'udi, Islam dan Hak-bak Reproduksi Perempuan, pp. 189-190.

${ }^{73}$ Ibid., pp. 81-82.

${ }^{74}$ Munawar-Rachman, Islam Pluralis, p. 406.
} 
killing (qisāss). In most cases, criminals are punished by imprisonment. ${ }^{75}$

There have been, however, isolated cases of the application of the shari' $a b$ in the area of criminal law, the most recent being the stoning to death (rajm) of a man who had committed adultery (zina), carried out by the militant Islamist group known as Lasykar Jibad (the Troop of Holy War). The sentence was apparently carried out following the personal confession by a member of this group that he had committed adultery with a woman on 23 March 2001 at Nusaniwe, a small village in Ambon, Molucca. This stoning is generally acknowledged to have been the first to occur in Indonesia since its founding as a secular state. On the basis of advice from a Muslim jurist in Yemen, and referring to the practice of the shari'ab during the time of the Prophet, the leaders of this group hold that committing adultery should be punished with one hundred lashes for those not yet married (zin $\bar{a}$ ghayru muhşan), or stoning to death for those already married (zina $\bar{a}$ mubsan), based either on personal confession or the testimony of four witnesses. ${ }^{76}$ It is stated that this punishment will release the perpetrator from God's punishment in the hereafter.

Understandably, the hudüd punishments are a controversial subject in Indonesia, since the prevailing criminal law in the country is secular, not the shari'ah (Islamic law). Moreover, even in Islam the authority to inflict stoning as punishment lies with the government, which in the case of Indonesia has chosen not to avail itself of such an option. Indeed, one of the chief problems with the application of budüd punishments is that they are inevitably perceived as a violation of human rights. Indonesian Muslim society likewise feels considerable anxiety over the criminal provisions of the shari'ah. Thus some Muslim intellectuals, such as Masykuri Abdillah, disagree with recent moves to apply in full the Jakarta Charter of 1945, and especially the "the seven omitted words" (kewajiban menjalankan syari'at Islam bagi para pemeluknya - the obligation of its adherents to observe the shari'ab), because this will imply that those Muslims who steal must be punished Press, 2000).

${ }^{75}$ See, for example, Ahmad Azhar Basyir, Ikhtisar Fikih Jinayat (Jogjakarta: UII

${ }^{76}$ See the Qur'ān, Sūrat al-Nūr, Q. 24:2; and also the Prophetic tradition narrated by al-Bukhārỉ and Muslim from Abū Hurayrah; Basyir, Ikhtisar Fikih Jinayat, pp. 43-44. 
by the cutting off of the hand and that those who commit adultery must be stoned. Since these rules would not apply to non-Muslims, inequality would be the result. ${ }^{77}$

Accordingly, no rulings of the shari'ah on criminal law are formally included in the national law of Indonesia. Nor does the Indonesian Law of Human Rights say anything about this crucial subject. Even the ICCPR presents only a few features of the extensive rights and procedural safeguards in the area of criminal procedure in articles 9 and 14. The Cairo Declaration then duplicates these in articles 19 and 20 , which deal with aspects of criminal justice. Shari'‘ ah law is believed to have been historically underdeveloped in the area of criminal procedure, and until the recent Islamization trend, it had long been abandoned in almost all countries and replaced by criminal procedure rules of Western provenance.

Mayer maintains that Islamic rules on criminal procedure "are not a facet of the Islamic legacy that has commanded much loyalty or that has constituted a serious obstacle to the modernization of criminal justice." 78 This fact, she goes on to say, makes it difficult for some to argue that the decision to omit from the Cairo declaration the safeguards of articles 9 and 14 of the ICCPR was "compelled by a generally accepted view of which elements in the Islamic legal legacy deserve high priority." 79 Article 19 (b) of the Cairo Declaration states that the right "to resort to justice is guaranteed to everyone." This formulation is regarded as fragile, since the declaration gives insufficient guarantee that this right "to resort justice includes a fair hearing with safeguard (for both civil and criminal litigants) according to the rights provided under international law." In addition, article 19 (d) states that "there shall be no crime of punishment except as provided for in the Shari'ah." This is in contradiction with article 15 of the ICCPR, which states that "no one shall be held guilty of any criminal offence on account of any act or omission which did not constitute a criminal offense, under national or international law, at the time when it was committed."

\footnotetext{
${ }^{77}$ From an interview with Masykuri Abdillah, April 2003, in Jakarta.

${ }^{78}$ Mayer, "Universal versus Islamic Human Rights", p. 334; referring to Amnesty International Report, 1993, p. 339.

${ }^{79}$ Ibid.
} 
In Islamic law in the past, there was no principle that an act had to be defined as a crime in the text of a law for it to be the basis for prosecution of punishment. Thus, the article 19 provision that there should be no crime or punishment except as provided for in the shari ${ }^{i} h$ seems to open the door to the application of discretionary ta izir penalties, where the judge assesses punishment according to his personal notion of what constitutes criminal behavior and what penalty should be imposed. Such discretionary justice, whether under the rubric of ta'ir or otherwise, is deeply ingrained in the legal system of Saudi Arabia, where both the dearth of codified law and the government's authority to interpret the scope of laws have meant that advance notice of what acts will be treated as criminal and what the applicable penalties will be is not provided to the public.

The principle set forth in article 19 (d) of the ICCPR, as already noted, allows the shari'ah to determine crimes and punishments (the hadd penalties). The latter, as set down in the Qur'an, either expressly or by implication, include flogging, amputation, stoning to death, and crucifixion. Qur'ānic qișass penalties include mutilation and execution imposed in retaliation for injuries or killing. The penalties had been abandoned in the criminal laws in almost all Muslim countries due to their unsuitability according to the standards of modern criminal justice, although Saudi Arabia is one of the rare exceptions in this regard. ${ }^{80}$

It may be useful at this point to recall ash-Shiddieqy's views regarding certain rights in light of his perception of Islamic values. With regard to the right to life and personal security, and the rights of self-protection, dignity and property for example, he asserts that Islam guarantees the right to life, and protects the soul and human dignity and property. Everyone has this absolute right, except in circumstances where its preemption is tolerated by the shari' $a$ h. Killing one man is equated with the killing of all human beings, since the act of killing is regarded as denying the right to life. The shari' ab confirms this principle,

${ }^{80}$ Ibid., pp. $340-341$. 
Ahmad Nur Fuad, et al.

for which ash-Shiddieqy cites al-Mà'idah (Q. 5:32) ${ }^{81}$ and al-Nisāa (Q.4:93). ${ }^{82}$

Islam does not simply submit this principle to the esoteric responsibility and sanction of the Hereafter, but insists that it be dealt with by the law in this world. It therefore prescribes qisass for intentional killing, and diyah and fidyab in the case of unintended killing. Qisās is to be determined in proportion to the fault committed. If anyone kills a person, the killer should be killed. In addition, to guarantee the safety of the human soul and property, Islam condemns any form of violation of human spirit or dignity. To preserve one's life, according to ashShiddieqy, an individual is even permitted in Islam to kill others who have food but do not want to share, when this food is needed for survival. Quoting Ibn Hazm, he asserts that if a member of a community dies of hunger, diyah is taken from the rest of the inhabitants in the city, because they are regarded as the killers. ${ }^{83}$

The prohibition of killing, suicide and other criminal actions towards human beings cannot be understood as curbs on personal freedom. Rather, their prohibition should be seen as God's way of conferring honor on humankind, His most exalted creature. Injustice and suicide, from the perspective of Islam, are regarded as actions destructive to the foundations of a noble and civilized humanity. God has in fact given to the human being the following: individual honor (karamah fardiyyah), through which his rights are respected and his blood and dignity preserved from harm, in keeping with Islam's respect for spiritual and material dignity (karämah ma'nawiyah-mäddiyyah); social honor (karamah ijtima'izyyah), through which equality among human beings is assured; and political honor (karamah siyäsiyyah), through which each human being has the right to choose and be chosen as a civic official, and enjoy all political rights. ${ }^{84}$

81 "That was why We laid down for the Israelites that whoever killed a human being, except as a punishment for murder or other wicked crimes, should be looked upon as though he had killed all mankind; and that whoever saved a human life should be regarded as though he had saved all mankind."

82 "He that kills a believer by design shall burn in Hell for ever."

${ }^{83}$ ash-Shiddieqy, Islam dan $\mathrm{H} A M$, p. 7.

${ }^{84}$ ash-Shiddieqy, Islam dan $H A M$, p. 7. 
Basing his arguments on Qur'ānic verses such as those in al-Isrā', (Q. 17:70), ${ }^{85}$ ash-Shiddieqy claims that it was Islam that, fourteen centuries ago, propagated the principles of human rights, not the French Revolution nor the UN committee charged with drawing up the Universal Declaration of Human Rights. Although this standpoint may seem apologetic, it can be justified since ash-Shiddieqy consistently advocated the Islamic values of human rights in his debates in the Konstituante as a representative of the Masyumi, an Islamic party.

The idea of implementing the budūd (corporal punishments) is thus not broadly favored among Muslim intellectuals. This fact is understandable, since there is a common opinion that such punishments are out of step with current notions of universal human rights. Some even regard this branch of Islamic law as inhuman and dreadful. It is important however to consider the interpretation of al$\mathrm{Na}$ 'im, who offers a new approach to Islamic criminal justice; he has even expressed the hope that his proposal for a reformed version of the budüd (sing. hadd) might be implemented by modern criminal justice systems everywhere. ${ }^{86}$ His ideas are based on what may be regarded as the rational argument - from a religious point of view at least - that human life does not end at death, but extends beyond that to the next, eternal life. Every human being will stand judgment and suffer the consequences of his or her actions in this life. It is his (and others') belief that punishments based on the shari'ab will release the offender from punishment in the next life, because God will not give punishment twice for the same crime. In this regard, therefore, a thief who suffers amputation of the right hand in this life will be spared an even worse punishment in the Hereafter. ${ }^{87}$

85 "We have bestowed blessings on Adam's children and guided them by land and sea. We have provided them with good things and exalted them above many of Our creatures."

${ }^{86}$ Abdullahi Ahmed an-Na'im, "Toward a Cross-Cultural Approach to Defining International Standards of Human Rights: The Meaning of Cruel, Inhuman, or degrading Treatment", in Human Rights in Cross-Cultural Perspectives, ed. Abdullahi Ahmed an-Na'im (Philadelphia: University of Pennsylvania Press, 1992), pp. 35-36.

${ }^{87}$ Ibid. 
Ahmad Nur Fuad, et al.

\section{E. Concluding Remarks}

The foregoing discussion reveals that, while there is a universal human rights standard on an international level, the understanding and implementation of these rights take place in multicultural contexts that must be given special consideration. Most Muslim intellectuals stress their Islamic identity and at the same time their belief in the universality of human rights standards. This of course highlights the intricate interplay between the particularity of Islamic culture and doctrine and the universality of human rights standards in the current world. These intellectuals seem to be aware that the modern concept of individual human rights has a European origin and acknowledge the difficulty of accommodating both the application of the shari'ah and universally accepted human rights standards.

As far as their respective philosophical foundations are concerned, we can see the difference between human rights as declared in the West and the human rights of Islam. In the UDHR, the human being is seen as his/her own master, whereas from the Islamic religious perspective, the human being is unequivocally a servant of God. The foundations of 'Islamic human rights' and those of the UDHR are therefore different. The former is theo-centric, while the latter is anthropocentric. Islamic principles are divine, while Western human rights are human. The latter therefore has no concern with such issues as, to choose but one example, zina (adultery). From the Islamic perspective, it is permitted for the police to enforce the law and arrest adulterers, whereas from a Western human rights point of view, the police would be violating individual rights if they did the same. And while some or all religious concepts of human rights have their parallels in Western human rights schemes, whether they are justified or not depends on how human beings define their religious teachings. Both Mas'udi and Abdullah al-Na'im for instance would say that there are no essential differences between the shari 'ah and universal human rights. Where there are differences, however, Mas'udi would take universal human rights as his parameters. The principles of the shari' $a h$ will be subordinated to those of human rights, Mas'udi assumes. ${ }^{88}$

\footnotetext{
${ }^{88}$ From an interview with Masdar F. Mas'udi, April 2003, in Jakarta.
} 
For a number of intellectuals, the application of universal human rights standards will help people to admit and exercise their individual rights, despite the fact that in certain cases these contradict the corpus of the shari'ah. Nor is the shari'ah itself free from criticism, even by Muslim scholars. Indonesian Muslim scholars who are inspired by such liberal thinkers as an-Na'im believe that that the application of the shari' $a b$ is undesirable because this would only contribute to establishing totalitarian regimes. An-Na'im argues that the shari"ab is "not the appropriate vehicle for Islamic self-determination in the present contexts." 89 The shari'ah was in fact constructed by Muslim jurists. Although derived from the Qur'an and Sunnah, it is not divine because it is the product of a human interpretation of those sources.

Most of the Indonesian Muslim intellectuals under review here highlight the importance of universal human rights, but their viewpoints seem to exhibit the necessity of Islamic human rights. They at least try to reconcile the substance of Islamic doctrine with the values of universal human rights. Observing all the points of view already mentioned, we can assert that most Indonesian Muslim thinkers are inclined to defend the belief that human rights values constitute part of the essence of Islam..$^{0}$ They tend to see no clear difference between human rights in the modern nation-state and human rights in Islam. Accordingly, it must be acknowledged that when a right is admitted in Islam, it often remains tied to its ethical and spiritual foundation, so that the assertion has something of the nature of an abstract discourse. Afshari observes that, although human rights do exist in Islam, they are still religiously "pious assertions," since there has been no effort taken to incorporate human rights within the constitutions of Muslim states. It is disappointing to see how difficult such states find it to give legal force to human rights. ${ }^{11}$ Komaruddin Hidayat argues that the normative values of Islam regarding human rights should be institutionalized at the social as well as at state levels so as to be binding

${ }^{89}$ An-Na'im, "Toward a Crocc-Cultural Approach”, p. 36.

${ }^{90}$ This is not peculiar to Indonesia, however; almost all Muslim scholars in various Muslim states have developed a similar viewpoint. See Afshari, “Essay”, pp. 235276.

${ }^{91}$ Ibid. 
on all humanity. In the contemporary context, Islam needs governments that can see their way towards implementing such values. In this case, the state serves as an effective means of implementing Islamic norms of human rights, while at the same time affecting a dialectical compromise with current social values and thinking. ${ }^{92}$

Therefore, for some Indonesian Muslim intellectuals, the present human rights standards are to a large degree assumed valid, since they reflect the normative framework of the common human experience not only at the theoretical, abstract level, but also in the face of expanding powers of the state and the realities of globalization in every part of the world today. It can be said that even though many Muslim scholars invoke the rhetoric of cultural relativism, they do not in fact reject the present set of internationally recognized human rights. Rather, they simply voice some reservations, while justifying the universality of human rights values in Islam.

It is apparent that, although some Indonesian Muslim intellectuals admit that universal human rights are truly universal, they still see differences in certain cases, due to differences in socio-cultural background. They have tried to affect a synthesis between the universality and particularity of both Islamic and universal human rights in order to make both fit within the Indonesian context. History will prove whether these efforts succeed.

\footnotetext{
${ }^{92}$ From an interview with Komaruddin Hidayat, 23 May 2003, in Jakarta.
} 


\section{BIBLIOGRAPHY}

Abdillah, Masykuri, Demokrasi di Persimpangan Makna, Jogjakarta: Tiara Wacana, 1999.

Afshari, Reza, "An Essay on Islamic Cultural Relativism in the Discourse of Human Rights," Human Rights Quarterly 16, 2 (May, 1994): 235-276.

Ali, A. Yusuf, The Meaning of the Glorious Qur'an, Beirut: Dar al-Kitab al-Lubnany, 1934.

Basyir, Ahmad Azhar, Ikhtisar Fikih Jinayat, Jogjakarta: UII Press, 2000. Bielefeldt, Heiner, "Muslim Voices in the Human Rights Debate," Human Rights Quarterly, 17, 4 (1995): 587-617.

Brohi, Allahbukhsh K, "Human Rights and Duties in Islam: A Philosophic Approach," in Salem Azzam (ed.), Islam and Contemporary Society, 248-249. New York: Longman, 1982.

Esposito, John L. and John O. Voll, Islam and Democracy, New York, Oxford: Oxford University Press, 1996.

Fukuyama, Francis, The End of History and the Last Man, New York: The Free Press, 1992.

Hassan, Riffat, "Religious Human Rights and the Qur'an," Emory International Law Review 10:1 (Spring, 1996): 85-96.

Hasyim, Syafiq, Hal-hal yang tak Terpikirkan: Tentang Isu-Isu Keperempuanan dalam Islam, Bandung: Mizan, 2001.

Henningsson, Jan, "Contemporary Understanding of Human Rights in Islam," in The Bulletin of the Henry Martyn Institute of Islamic Studies, vol.14, Nos. 3\&4 (July-December 1995): 84-104.

Huntington, Samuel, "The Clash of Civilization." Foreign Affairs 72, no. 3 (Summer, 1993): 22-49.

Lopa, Baharuddin, al-Qur'an \& Hak-hak Asasi Manusia, Jakarta: Dana Bhakti Prima Yasa, 1996.

Ma'arif, Ahmad Syafi'i, Islam dan Masalah Kenegaraan, Jakarta: LP3ES, 1985. 
Ahmad Nur Fuad, et al.

Madjid, Nurcholish, Islam, Doktrin dan Peradaban, Jakarta: Paramadina, 1992.

Mas'udi, Masdar, "Hak Asasi Manusia dalam Islam," in E. Shobirin Nadj and Naning Mardianah (eds.), Diseminasi Hak Asasi Manusia: Perspektif dan Aksi, Jakarta: LP3ES, 2000.

----, Islam dan Hak-hak Reproduksi Perempuan, Bandung: Mizan, 1997.

Mayer, Ann Elizabeth, "Universal versus Islamic Human Rights: A Clash of Cultures or A Clash with a Construct?", Michigan Journal of International Law, vol.15:307 (Winter, 1994):308-404.

Munawar-Rachman, Budhy, Islam Pluralis, Jakarta: Paramadina, 2001. an-Na'im, Abdullahi Ahmed (ed.), Human Rights in Cross-Cultural Perspectives, Philadelphia: University of Pennsylvania Press, 1992. Nasution, Adnan Buyung, Aspirasi Pemerintahan Konstitusional di Indonesia: Studi Sosio-Legal atas Konstituante 1956-1959, Jakarta: Grafiti, 1995. Nasution, Harun and Bahtiar Effendy, Hak-hak Asasi Manusia dalam Islam, Jakarta: Pustaka Firdaus and Yayasan Obor Indonesia, 1987.

Nasution, Khoiruddin, Status Wanita di Asia Tenggara: Studi Terbadap Perundang-Undangan Perkawinan Kontemporer di Indonesia dan Malaysia, Jakarta: INIS, 2002.

Ramage, Douglas E, Politics in Indonesia: Democracy, Islam and the Ideology of Tolerance, London, New York: Routledge, 1995.

Ash-Shiddieqy, Teungku Muhammad Hasbi, Islam dan HAM [Hak. Asasi Manusia]: Dokumen Politik Pokok-pokok Pikiran Partai Islam dalam Sidang Konstituante 5 Februari 1958, re-edited by Fuad Hasbi ashShiddieqy, Semarang: Pustaka Rizki Putra,1999.

Tamara, M. Natsir \& Elza Peldi Taher, Agama dan Dialog Antar Peradaban, Jakarta: Paramadina, 1996.

Tibi, Bassam, "Islamic Law / Shari'a, Human Rights, Universal Morality and International Relations", Human Rights Quarterly 16, 2 (May, 1994): 277-299. 
Islam and Human Rights in Indonesia

\section{Interviews}

Dr. Komaruddin Hidayat (20 May 2003)

Drs. Masdar F. Mas'udi (21April 2003)

Dr. Masykuri Abdillah (28 April 2003)

Dr. Nurcholish Madjid (25 May 2003) 